\title{
Physical Education and Sports Lesson from Science High School Students' Perspective: Mixed Research Approach
}

\author{
Aynur Yilmaz \\ Correspondence: Aynur Yilmaz, Trabzon University Faculty of Sport Science, Turkey.
}

Received: February 17, 2019

doi:10.11114/jets.v7i4.4030

\author{
Accepted: March 11, $2019 \quad$ Online Published: March 13, 2019 \\ URL: https://doi.org/10.11114/jets.v7i4.4030
}

\begin{abstract}
The aim of this study is to investigation the opinions of science high school students about physical education and sports lesson. The research is designed with an exploratory sequential pattern from mixed research approaches. The research was carried out in two Science High Schools in Kırıkale province during the fall semester of 2017-2018 academic years. The study was conducted on three groups [first study group: 245 (141 females; 104 males); second study group: 24 (14 females; 10 males); third study group: 8 (7 female; 1 male)]. Quantitative data were obtained through the "Personal Information Form" prepared by the researcher and the "Physical Education Attitude Scale for Secondary School Students" developed by Güllü and Güçlü (2009). Qualitative data were collected by using the drawing-writing form and semi-structured interview form. Descriptive statistics, independent group t-test, one-way analysis of variance and Pearson correlation analysis were used to analyze the quantitative data. In the analysis of qualitative data, content analysis was utilized. According to the findings, it was found that the attitudes of science high school students towards physical education lesson were at a moderate level and male students had a more positive attitude than female students. There was no difference between academic achievement and class level.
\end{abstract}

Keywords: attitude, science high school student, drawing-writing technique, interview, mixed research

\section{Introduction}

Education provides individuals with the skills they will need for life. The individual obtains these skills through different educational systems. Physical education is a concept in the education system and complementary to education. It contributes too many areas of development individual, including physical, social, psychological/spiritual, emotional and cognitive. Studies show that physical education also has an important role in personality development (Özkara, 2018; Yılmaz, 2018a; Yılmaz \& Cihan, 2018). Therefore, developing a positive attitude towards physical education offers the opportunity to benefit from its effects to the individual's development.

Attitudes are defined as the process of spiritual and neural preparation that has a direct and dynamic effect on the behaviors of the individual as a result of experience (Allport, cited from Freedman, 1993). The positive attitude towards the physical education lesson motivates the students to participate in this lesson and to make efforts to get the knowledge and skills related to the content of the lesson. In their study, Kjønniksen, Fjørtoft \& Wold, (2009) found that the positive attitude of the students towards the physical education curriculum encourages the students to learn the skills in physical education, enables them to take their health seriously, and motivates the students about their active participation in physical activity after school for this purpose. While physical education, which includes the intention of improving the physical and mental well-being of man and strengthening his will, are based on the physiological and muscular development of humans prior to the idea of human training through physical movements (Tamer \& Pulur, 2001). In the training of individuals with these characteristics, it is observed that physical education does not only contribute to biological development, but also decreases syndromes such as depression, stress, anxiety, and increases self confidence and self-esteem of the individual (Morgan, Saunders \& Lubans, 2012). Physical education constitutes a basis for providing the individual with behavior of doing physical activity. The individual who gains this behavior makes the sport the philosophy of life and keeps it at the center of his/her life. Physical education (PE) in school directly affects physical activity (PA) of a child in general, as well as the adoption of healthy lifestyle in general (Jusisin, Malcic \& Kostovic, 2017). The primary objective of physical education is developing positive attitudes in children to promote lifelong physical activity (Chatterjee, 2013; Sollerhed, Ejlertsson \& Apitzsch, 2005; Zeng, Hipscher \& Leung, 2011). Regular PA has enormously positive effects on well-being, and different health dimensions: biological as well as mental, emotional and social (Strong et al. 2005). 
Results of available studies confirm that the positive attitude of children towards PE is positively correlated with their academic success (Howie \& Pate, 2012; Kirkendall, 1986; Taras, 2005; Trudeau \& Shephard, 2008; Y1lmaz, 2018). However, the aforementioned studies failed to test the feedback, i.e. whether better academic success affects the more positive attitude towards PE. The fact that academic success is a factor shaping the future of individuals in our society leads to anxiety in students and parents. The fact that the physical education curriculum is not carried out in accordance with its purpose causes the lesson to be perceived as wasted time by students and parents (Y1lmaz \& Cihan, 2018). It is important to determine the opinions of science high school students, constituting the aim of the study, on the physical education lesson and to figure out the effect of physical education on the academic achievement of this academically successful group. For this purpose, the following questions were answered.

1. What is the mean score of students' attitude towards physical education lesson?

2. Does the mean score of students' attitude towards physical education lesson change significantly according to gender, class level, academic grade point average, and status of doing sports?

3. How do students with low and high scores describe how they want a physical education lesson in their drawings?

4. What are the reasons why students have negative opinions about physical education lesson?

\section{Method}

\subsection{Research Design}

After determining the attitudes of science high school students towards physical education lesson, mixed model approach is used in this research, in which the participants reflected their opinions on the physical education lesson and presented their opinions about what kind of physical education lesson they want with the reasons and these reasons were examined in detail by interview. In this study, Explanatory Sequential design is used, one of the mixed research approaches (Creswell, 2014). This design is a process in which quantitative data were first collected and analyzed, and then the qualitative data were collected and analyzed (Creswell \& Clark, 2007) in order to build the data obtained on a solid ground. In the first stage of the process, the researcher uses two project stages, including quantitative data collection and analyzing the findings in the first stage and then planning the second stage using the findings (Creswell, 2014).

In order to determine the attitudes of the students towards physical education lesson, firstly, students who have the highest and lowest physical education attitude scores were determined by using quantitative data collection tool. By doing deviant case sampling, the students with low and high score for the physical education lesson were asked to draw a picture, including their thoughts about the physical education lesson and how they had imagined a physical education lesson, adding the reasons. These drawings and statements were analyzed in accordance with the general points of view of physical education lesson and the learning outcomes of physical education lesson. Afterwards, semi-structured interview technique was used for the students with negative opinions about physical education lesson and the reasons underlying these opinions in their drawings and their statements related to these drawings. In the research reports, it is thought that the use of multiple data collection techniques together is important for improving the reliability and validity of the comments made for the solution of the problem. For this reason, different data collection techniques were used to investigate the research problem in detail. The fiction of the research is shown below in Figure 1

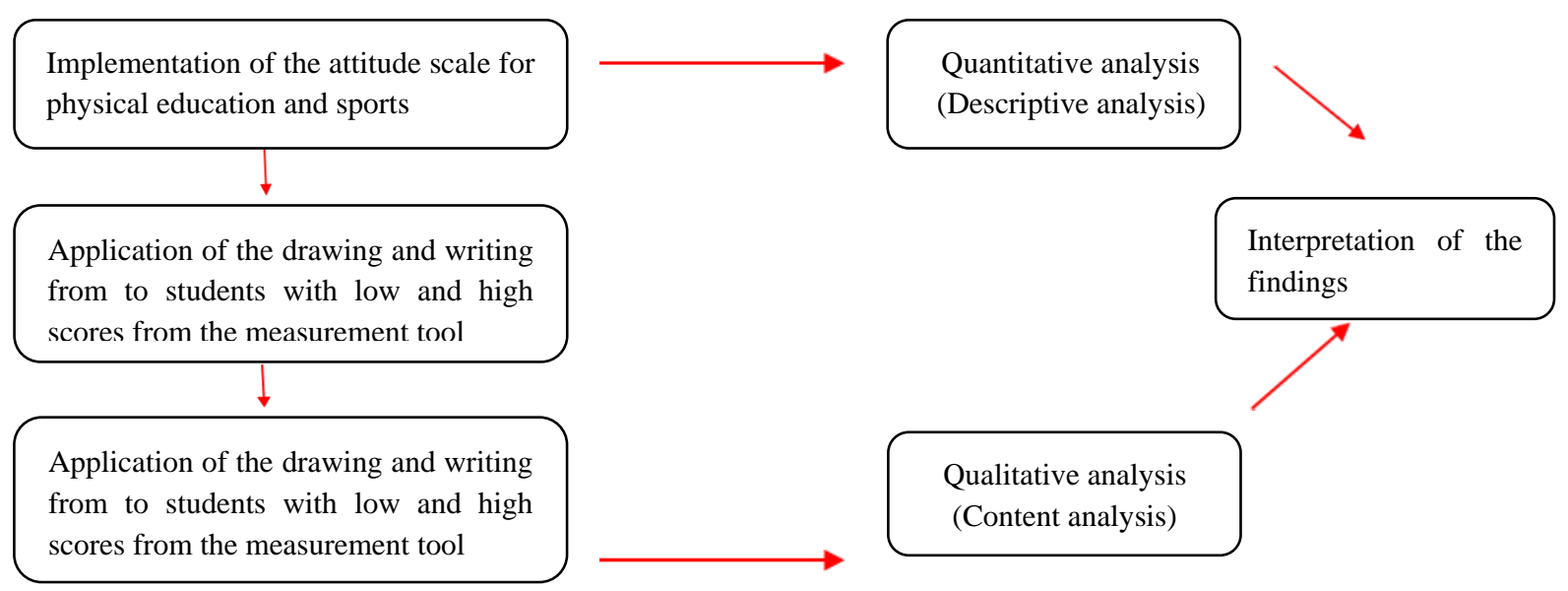

Figure 1. Flowchart of the research 


\subsection{Study Group}

In order to examine the opinions of science high school students on physical education, data from three different study groups were collected in the study fictionalized with mixed research approach. This study was carried out with the findings obtained from three groups.

\subsubsection{Study Group 1}

The study was carried out on 245 students (9th class $=122$, 10th class $=81$ and 11th class $=42$ ) studying at different class levels in the Science High School, one of the state schools in Kirkkale, in the first semester of 2017-2018 academic year. Of these students, $141(57.6 \%)$ were female and 104 (42.4\%) were male. The school where the study was carried out is one of the two science high schools in Kırıkkale. In this school, physical education and sports lessons are carried out by a teacher with 5 years of service experience. There is no gymnasium as the application area of physical education lesson. Lessons are carried out in the garden of the school.

\subsubsection{Study Group 2}

In the formation of the study group, deviant case sampling techniques from the purposeful sampling methods were used. In this sampling method, the sample is created from the deviant (extreme) situations and samples related to the problem (Yıldırım \& Şimşek, 2011). As a result of the quantitative analysis, 12 high school students who received the highest score and lowest score from the physical education attitude scale were included in the qualitative part of the study. Twelve of them are students who have a high attitude towards physical education lesson and are considered as upper group, and 12 of them have low scores for physical education lesson and are considered as sub-group in the study. Of the 24 students, 14 were female and 10 were male. The codes, classes and genders of students with positive and negative attitudes are shown in Table 1.

Table 1. The characteristics of students to whom the drawing and writing form applied

\begin{tabular}{cccccccccccc}
\hline & \multicolumn{3}{c}{ Sub Group } & \multicolumn{4}{c}{ Upper Group } \\
\hline & Gender & Class & & Gender & Class & & Gender & Class & Gender & Class \\
\hline$* \mathrm{P} 1$ & Female & $11^{\text {th }}$ & $* \mathrm{P} 7$ & Female & $10^{\text {th }}$ & $\mathrm{P} 13$ & Male & $11^{\text {th }}$ & P19 & Female & $9^{\text {th }}$ \\
\hline$* \mathrm{P} 2$ & Female & $9^{\text {th }}$ & P8 & Female & $10^{\text {th }}$ & P14 & Male & $9^{\text {th }}$ & P20 & Male & $9^{\text {th }}$ \\
\hline$* \mathrm{P} 3$ & Female & $10^{\text {th }}$ & $* \mathrm{P} 9$ & Female & $10^{\text {th }}$ & P15 & Male & $10^{\text {th }}$ & P21 & Female & $10^{\text {th }}$ \\
\hline P4 & Female & $11^{\text {th }}$ & $* \mathrm{P} 10$ & Female & $9^{\text {th }}$ & P16 & Female & $9^{\text {th }}$ & P22 & Male & $10^{\text {th }}$ \\
\hline P5 & Female & $11^{\text {th }}$ & $* \mathrm{P} 11$ & Female & $11^{\text {th }}$ & P17 & Male & $9^{\text {th }}$ & P23 & Male & $9^{\text {th }}$ \\
\hline$* \mathrm{P} 6$ & Male & $10^{\text {th }}$ & P12 & Female & $10^{\text {th }}$ & P18 & Male & $11^{\text {th }}$ & P24 & Male & $11^{\text {th }}$ \\
\hline
\end{tabular}

*Students attending the interview

Table 1 shows the characteristics of the students whom the drawing and writing form applied to. Of these students, 11 of the students included in the sub group are female and only one is male. Two of these students are in the 9th class, 6 are in the 10th class and 4 are in the 11th class. In the quantitative part of the study, 9 of the students with a high score in the scale were male and 3 were female. Six of these students are in the 9th class, 3 are in the 10th class and 3 are in the 11 th class.

\subsubsection{Study Group 3}

As a result of content analysis for the drawings of 24 students, an interview was carried out for the reasons for this negativity with 8 students, 1 male $\left(\mathrm{P}_{6}\right)$ and 7 females $\left(\mathrm{P}_{1}, \mathrm{P}_{2}, \mathrm{P}_{3}, \mathrm{P}_{7}, \mathrm{P}_{9}, \mathrm{P}_{10}, \mathrm{P}_{11}\right)$ who made negative drawings and statements about physical education lesson. These interviews are between 5 and 9 minutes.

\subsection{Data Collection}

In the study, "Personal Information Form", "Physical Education Lesson Attitude Scale", "Drawing and Writing Form" and "Semi-Structured Interview Form" were used as data collection tools.

\subsubsection{Quantitative Data Collection}

Personal Information Form: In order to determine the attitudes of science high school students towards physical education lessons, a Personal Information Form was prepared by the researcher. This form includes independent variables such as participants' gender, academic grade point average, class level, status of doing sports.

Physical Education Lesson Attitude Scale: The "Physical Education Attitude Scale for Secondary School Students" was used, reliability and validity study of which was made by Güllü and Güçlü (2009). This measurement tool consists of a 
total of 35 items with 11 negative and 24 positive and a single factor structure. The measurement tool is 5-point Likert type and the lowest and highest point that can be taken from the measurement tool is 35 and 175 . The reliability values of the original scale were 0.80 for t-retest and the Cronbach Alpha internal consistency coefficient was 0.94. In the current study, the reliability of the scale was tested. The Cronbach alpha internal consistency coefficient, which was calculated through the data collected within the scope of this research, was found to be 0.92 .

\subsubsection{Qualitative Data Collection}

Drawing and Writing Form: In this study, drawing-writing form was used as data collection tool. This technique (form) is a qualitative data collection technique that involves the individual drawing a picture and writing any thoughts and related ideas about this picture in order to explain the research question or a theme (Bradding and Horstman, 1999). The drawings are important in terms of expressing the existing knowledge and beliefs of students without being bound by words (Ayas, 2006) and obtaining the natural and high quality data about the hidden thoughts, meanings and attitudes (Backett and McKie, 1999).

In this study, the students were asked to draw a picture on what they think about physical education lesson and how they imagine a physical education lesson. The students were asked to write the statements on what they have included in these drawings about the physical education lesson. While forming a data collection tool, opinions of experts, 1 from the assessment and evaluation field, 2 from the physical education field and 1 from the preschool field were received. In addition, the literature review was performed to evaluate the drawing and writing form and the studies using the drawing adn writing technique were examined (Ersoy and Turkkan, 2009; Knighting et al., 2011; Taneri and Demir, 2013; Yalcin and Erginer, 2014; Yilmaz and Guven, 2015; Yilmaz, Esenturk, Pala and Ilhan, 2017) and these data were used during the preparation of data collection tool. The data collection tool was finalized according to all these steps. The drawing and writing form consists of two parts. In the first part, there is personal information form, which includes independent variables such as gender, class level, sporting status, academic grade point average, and in the second part, the following questions are given: "Make a drawing explaining how you want a physical education lesson? And what do you want to tell us in your drawing, please write.

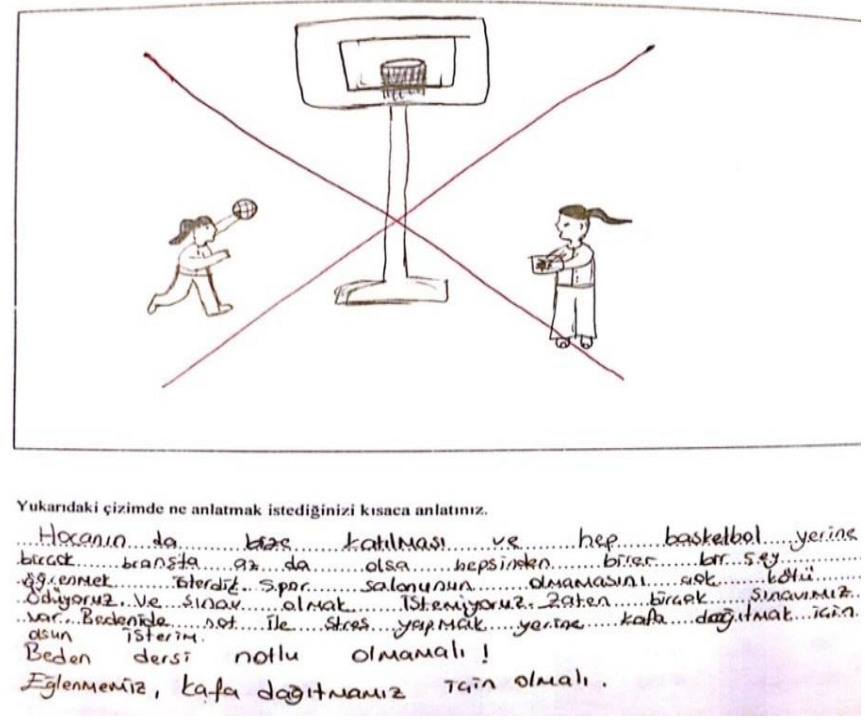

Figure 2. P3 (Subgroup, Female, $10^{\text {th }}$ class)

Semi-Structured Interview Form: In order to reveal the reasons under the negative thoughts of the students about the physical education lesson, the students were asked questions such as the reasons they do not like physical education lesson and how they want a physical education lesson. Before the questions were prepared, the learning outcomes of the physical education lesson were taken into consideration. After the interview form was prepared, opinions of four experts, the two faculty members in the field of physical education and sports, one in the field of assessment and evaluation and one in the field of Turkish education, were used before finalizing the semi-structured interview form. The final interview form was prepared in accordance with the feedback from them. The interviews were conducted in line with the drawings and statements students made about the question of what kind of a physical education lesson you dream. The questions in the interview form are given below:

1. What do you tell us in your drawing? 
2. What are your general thoughts about physical education and sports lesson?

3. What are the reasons for your negative thoughts about physical education and sports lesson? Please explain.

4. Does your physical education teacher have a share in these thoughts?

5. Well, what kind of physical education lesson do you want?

In the interviews made considering the students' drawings, the reasons of negative thoughts of students were tried to be understood. Interviews were conducted in a free lesson time period. Interviews were conducted one-to-one and the environment is free of elements that may affect the course of the interview. With the consent of the students, the interviews were recorded on the voice recorder.

\subsection{Data Analysis}

\subsubsection{Analysis of Quantitative Data}

The data obtained from the research were analyzed by SPSS 22 Statistical Package Program. Frequency, arithmetic mean, standard deviation, Independent group t-test, One-Way Variance Analysis and Pearson Correlation test were used in statistical analysis of data. It was decided whether the data were met by the prerequisites of parametric tests by evaluating the Skewness and Kurtosis values and Levene test results (Büyüköztürk, 2008). Content analysis technique was used in the analysis of the findings obtained in the qualitative part.

\subsubsection{Analysis of Qualitative Data}

In the qualitative part of the study, analyzes obtained from two different data collection tools are included. How the students want a physical education lesson was reflected in the data obtained by using the drawing and writing technique. The interview forms obtained from the interviews with the students who gave negative statements in the drawings were subjected to content analysis. Content analysis involves gathering data that are similar to each other in terms of specific concepts and themes, and editing and interpreting them in a way that the reader can understand (Yildırım and Șimșek, 2011).

Drawing and Writing Form: Before starting the content analysis, drawing and writing forms of the students with a high mean score from the scale were numbered from U1 to U12. Other drawing and writing forms were classified from S1 to S12. While analyzing the drawings of the students in both the upper and sub groups, how the content of a physical education lesson should be and the learning outcomes of lesson and how the lesson should be carried out in a classroom atmosphere were taken into consideration. Since the drawings were suitable for the purpose of the research, no drawing and writing form was excluded from the analysis. In addition, the elements which are included in the physical education lesson in the students' dreams were taken into consideration in the coding. In qualitative analysis, coding for the analysis of the contents of the data is the initial and essential process (Punch, 2005). The coding process was carried out independently by two researchers. A code list was created in accordance with the criteria determined. By looking at the relationship between these codes, the categories that can explain the feature best were reached and the data was tried to be made significant.

Semi-Structured Interview Form: This was carried out to determine the reasons for the students' negative opinions about the physical education lesson in the drawing and writing form. The interview forms obtained as a result of these interviews were analyzed in accordance with the research problem. The interviews were conducted with 7 females and 1 male student. The data obtained were first written by the researcher. Then, it was submitted to the control of the students to check for any deficiencies or mistakes. As a result of the analysis of the opinions reflected in the drawings, it was determined that female students formed the general students with the negative thoughts. Analyzes were also made by taking into account the gender element.

\subsection{Validity and Reliability}

\subsubsection{Validity and Reliability for Quantitative Data}

The validity and reliability analysis of the student attitude scale for physical education and sports was re-tested on the current study group. Construct validity was performed by Confirmatory factor analysis within the scope of validity. The fit indices obtained as a result of CFA were found to be $\chi 2 / \mathrm{df}=1.48, \mathrm{RMSEA}=0.07, \mathrm{GFI}=0.89, \mathrm{AGFI}=0.865, \mathrm{CFI}=0.94$, $\mathrm{NFI}=0.94$, IFI=0.94, PNFI=0.85. These values showed that 35 items and one-dimensional structure of Physical Education Attitude Scale for Secondary School Students validated by Güllü and Güçlü (2009) were verified on the current study group. It was determined that the item-factor load values of the scale items were between 0.54 and 0.75 , and t-values ranged between 11.95 and 17.40. The Cronbach Alpha reliability coefficient was calculated as 0.92 in the present study. According to these findings, it can be said that the measurement tool makes a valid and reliable measurement. 


\subsubsection{Validity and Reliability for Qualitative Data}

Within the scope of external reliability, inter-encoders consensus was calculated. For this coefficient, the formula of agreement correlation coefficient between the researchers [Consensus/(Consensus + Dissensus)x100] was used, which was revealed by Miles and Huberman (1994). In this study, this value was calculated as 0.91. When the percentage of conformity in the reliability calculation is $70 \%$, the percentage of reliability is considered reached (Yıldırım and Şimşek, 2011). This shows that the researchers who conduct the analysis are consistent within themselves. In addition, drawings and student opinions are included to provide proof of validity.

\section{Results}

In the study designed with mixed research approach, firstly, the quantitative data were analyzed and then the findings obtained as a result of the qualitative research were given in order to examine the quantitative findings in depth.

\subsection{Quantitative Results}

In this section, the results between the gender, class level, academic grade point average and sport making variables and mean scores obtained from the scale are given to test the attitudes of science high school students towards physical education lesson.

Table 2. Score Distributions of Measurement Tool

\begin{tabular}{lcccccccc}
\hline Scale & $\begin{array}{c}\text { Number of } \\
\text { Items }\end{array}$ & $\mathrm{N}$ & $\overline{\mathrm{x}}$ & $\mathrm{Sd}$ & Skewness & Kurtosis & Min. & Max. \\
\hline Physical Education Lesson Attitude & 35 & 245 & 3.21 & 0.98 & -0.60 & -0.31 & 1.29 & 5.00 \\
\hline
\end{tabular}

According to Table 2, it appears that the scale means score of the students for physical education and sports lesson is $3.21 \pm 0.98$. This shows that the attitudes of science high school students towards physical education and sports lesson are at the moderate level. It can be said that the distribution is between normal values considering the skewness $(-0.60)$ and kurtosis (-0.31) values of the measurement tool.

Table 3. Results of T-Test Analysis for the Relationship of the Scale Score Mean with Gender

\begin{tabular}{ccccccc}
\hline Gender & \multicolumn{2}{c}{$\begin{array}{c}\text { Female } \\
(\mathrm{n}=141)\end{array}$} & \multicolumn{2}{c}{$\begin{array}{c}\text { Male } \\
(\mathrm{n}=104)\end{array}$} \\
\hline Physical Education Lesson Attitude & $\mathrm{x}$ & $\mathrm{Sd}$ & $\overline{\mathrm{x}}$ & $\mathrm{Sd}$ & $\mathrm{t}$ & $\mathrm{p}$ \\
\hline $\mathrm{p}<.05^{*}$ & 3.10 & 0.78 & 3.35 & 0.76 & -2.544 & $\mathbf{0 . 0 1 *}$ \\
\hline
\end{tabular}

In Table 3, the mean score of the science high school students from the physical education lesson attitude scale shows a significant difference according to gender $(\mathrm{p}<.05)$. Considering the mean scores, it was found that the male students' attitude scores towards physical education lesson $(3.35 \pm 0.76)$ were higher than that of female students $(3.10 \pm 0.78)$. This shows that male students 'attitudes towards physical education lesson are higher than female students' attitudes.

Table 4. One-Way Analysis of Variance Results for Determining Whether the Scale Score Mean Shows Differences according to Class Level

\begin{tabular}{lcccccccccc}
\hline Class Level & \multicolumn{2}{c}{9} & \multicolumn{1}{c}{10} & \multicolumn{2}{c}{11} \\
$(\mathrm{n}=122)$ & \multicolumn{2}{c}{$\begin{array}{c}(\mathrm{n}=81) \\
(\mathrm{n}=42)\end{array}$} & & & & \\
\hline & $\overline{\mathrm{x}}$ & $\mathrm{Sd}$ & $\overline{\mathrm{x}}$ & $\mathrm{Sd}$ & $\overline{\mathrm{x}}$ & $\mathrm{Sd}$ & $\mathrm{F}$ & $\mathrm{p}$ & $\mathrm{MD}$ \\
\hline Physical Education Lesson Attitude & 3.28 & 0.75 & 3.04 & 0.86 & 3.30 & 0.70 & 2.58 & 0.07 & - \\
\hline
\end{tabular}

*MD: Meaning Differences

According to Table 4, the mean scores of the students from the attitude scale for the physical education lesson do not show a significant difference according to their class level ( $p>.05$ ). This can be interpreted that there is no effect of class level variable on the attitude of science high school students towards physical education lesson. 
Table 5. Results of Correlation Analysis to Test Whether There is a Significant Relationship between Attitude Score Mean and Academic Grade Point Average

\begin{tabular}{|c|c|c|c|}
\hline & \multicolumn{3}{|c|}{ Academic Grade Point Average } \\
\hline & $\mathrm{N}$ & $\mathrm{R}$ & $\mathrm{p}$ \\
\hline Physical Education Lesson Attitude & 245 & -.083 & 0.19 \\
\hline
\end{tabular}

According to Table 5, no significant relationship was found between the mean score of the students from the physical education lesson attitude scale and their academic grade point average ( $p>0.05)$. It can be said that the students' academic grade point average is not a determining variable for their attitudes towards physical education lesson.

Table 6. Results of the T-Test Analysis for the Relationship between the Attitude Scale Score Mean and the Status of Doing Sports

\begin{tabular}{lcccccc}
\hline Situation of Doing Sports & \multicolumn{3}{c}{ Yes $(\mathrm{n}=177)$} & \multicolumn{2}{c}{ No $(\mathrm{n}=68)$} \\
\hline & $\mathrm{x}$ & $\mathrm{Sd}$ & $\mathrm{x}$ & $\mathrm{Sd}$ & $\mathrm{t}$ & $\mathrm{p}$ \\
Physical Education Lesson Attitude (Total) & 3.35 & 0.74 & 2.74 & 0.79 & 4.665 & $\mathbf{0 . 0 0} *$ \\
\hline
\end{tabular}
$* \mathrm{p}<. \overline{05}$

According to Table 6, the mean score from the physical education lesson shows a significant difference according to the students' situation of doing sports ( $\mathrm{p}<0.05$ ). This difference is in favor of students engaged in sports. Students who are active in sports have higher attitudes towards physical education lesson than the students who do not do sports.

\subsection{Qualitative Results}

This part of the research includes the findings obtained as a result of the analysis of the drawings and interviews. The analyses of the answers to the question of what kind of a physical education lesson do you dream are given below.

Table 7. Opinions of students with low attitudes for the physical education lesson in their drawings

\begin{tabular}{|c|c|c|}
\hline Categories & Statements & Frequency \\
\hline \multirow{9}{*}{$\begin{array}{l}\text { Expectations for the } \\
\text { Application of the } \\
\text { Lesson }\end{array}$} & $\begin{array}{l}\text { Introduction and implementation of different sportive activities should be } \\
\text { included }\end{array}$ & 8 \\
\hline & Activities to improve students' sportive skills should be included & 5 \\
\hline & Increasing the lesson time for learning skills & 4 \\
\hline & Physical education lesson should not be compulsory & 3 \\
\hline & Physical and physiological problems of students should be taken into & 2 \\
\hline & consideration in the applications within the lesson & \\
\hline & $\begin{array}{l}\text { Opportunity to perform adequate practice for skill acquisition should be given } \\
\text { (The lesson has to be learned in the lesson) }\end{array}$ & 2 \\
\hline & Different techniques should be used for better learning skills & 2 \\
\hline & Total & 26 \\
\hline \multirow{6}{*}{$\begin{array}{l}\text { Expectations for } \\
\text { Assessment and } \\
\text { Evaluation }\end{array}$} & Physical education lesson should not affect academic grade point average & 6 \\
\hline & Effort and wish should be taken into consideration in the evaluation & 5 \\
\hline & Every individual should be evaluated according to his/her own abilities & 5 \\
\hline & (Absolute evaluation) & \\
\hline & $\begin{array}{l}\text { There should be no practice in physical education lesson (Anxiety for effect of } \\
\text { being unable to perform ability on academic grade point average) }\end{array}$ & 2 \\
\hline & Total & 18 \\
\hline \multirow{4}{*}{$\begin{array}{l}\text { Expectations for the } \\
\text { Learning Outcomes of } \\
\text { the Lesson }\end{array}$} & It should enable students to entertain and have a good time & 4 \\
\hline & It should give opportunity to socialize & 3 \\
\hline & It should support physical development & 2 \\
\hline & Total & 9 \\
\hline
\end{tabular}

*Sub group: Students with low attitude ( $\mathrm{n}=12)$

Table 7 shows the results of the drawing and statements of the students, who have a low mean score from the attitude scale for physical education lesson; they made to show what kind of lesson they want. Students were examined under three categories: the application of the lesson, the assessment and evaluation, and the expectations for the learning outcomes of the lesson. It is observed that the "Expectations for application of the lesson" show difference in the statements of the drawings. The students stated that knowledge and skills about different sportive activities should be gained in the physical education lesson, the two-hour practice is insufficient in gaining a skill, the teacher should actively participate in the activities applied in the lesson and the content of the lesson should be presented in a fun way to the students. Some of the students' drawings and opinions about the physical education lesson are given below. 


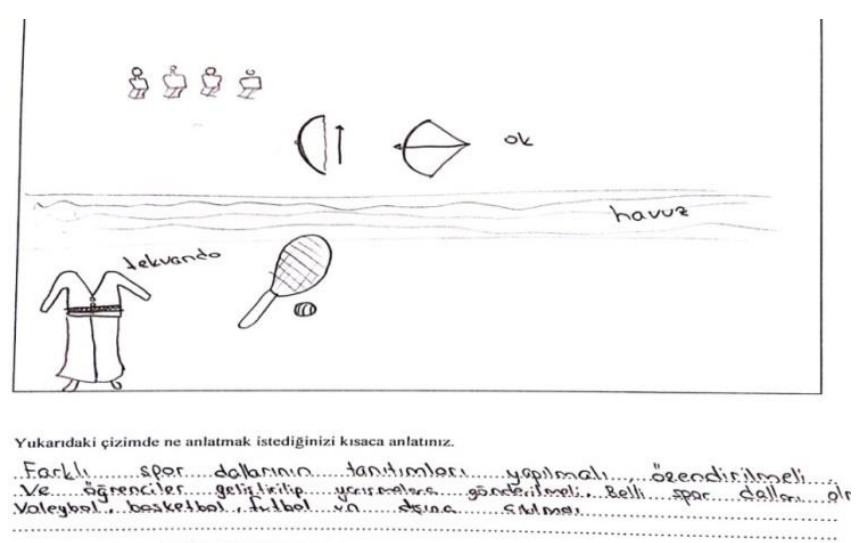

Figure 3. P7 (Sub group, Female, $10^{\text {th }}$ class)

Figure 3 shows the drawing and statement of the student for how the physical education lesson should be taught. Examples from the opinions of some students with low attitudes for the way of teaching the lesson are presented below:

"Physical education lesson lays the foundation of sports. Teachers who give the ball to children and let them free in primary and secondary school should also be aware of this and fulfill their duties in full. Physical education lesson does not consist of only wearing training suit. This is not the sport. Every child has an ore in him/her. You need to uncover it in lessons" (Female, P2, 9th class)."

"Sports incentive activities should be presented, students should discover their talents and improving applications should be included. In addition, you should introduce different activities other than volleyball, basketball and football branches, and athletes should be trained in these branches (Female, P1, 11th class)."

"This course should be free and the student should do whatever s/he wants. Students should not be forced for something. It should not affect our other lessons very much, because performing a skill depends on the ability. This lesson is fun for the talented student but is a torture for the untalented ones (Female, P7, 10th class)."

Table 6 shows that opinions of the students who have low attitudes towards physical education lesson differ for the assessment and evaluation in physical education lesson. As the physical education lesson is a skill-demanding lesson, students stated that the participation in the lesson and the effort to perform the skills should be taken into consideration in the evaluation. In addition, the students emphasized that there should not be a physical education lesson test, if there should be, then it should not be practical, because sport requires talent and it is not in every student. Drawings and opinions of some students with low attitudes for the assessment and evaluation in physical education lesson are given below.

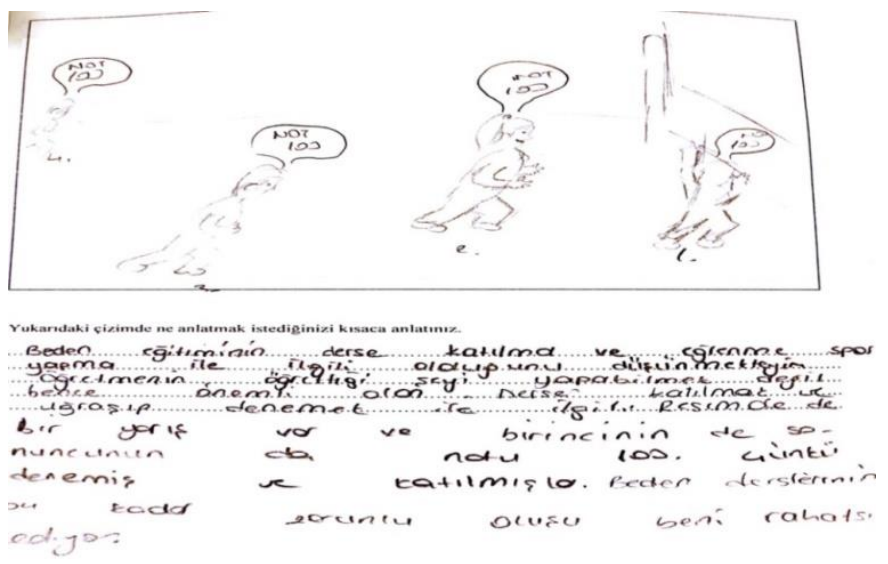

Figure 4. P4 (Sub group, Female, $11^{\text {th }}$ class)

In Figure 4, one of the students included the drawing and statement of how the evaluation of the physical education lesson should be. In the drawing, students are in a footrace. At the end of the race, the student reflected in her drawing that everyone should be given 100 regardless of whether they rank 1st, 2nd, 3rd and so on. She also stated that participating in the lesson and trying to perform the skill are sufficient to get good points from the lesson. The opinions of the other students related to this category are given below.

"There shouldn't be an exam. I think that this lesson is an escape and relaxation tool for resting our head and 
decreasing the stress of examination. I'm already stressed out. I also don't want to stress over the exam of the physical education lesson (Female, P3, 10th class)."

"What I don't like is that we get points as a result of sportive events that we perform. For me, everyone is not interested in sports, and it is difficult for someone, who has nothing to do with the sports, to get a high score. I think the exam of the lesson should not be practical" (Female, P7, 10th class).

"For me, the physical education lesson requires skill. So you may not be able to perform the skill. For example, people may have a weight problem, which may lead the individual to move difficultly. Rather than being able to perform the skill, trying to perform the skill should be taken into consideration. If there is no point application, this time the lesson is not taken seriously (Female, P2, 9th class)."

"Physical education lesson should be a lesson which we will participate in, which will enable us to have fun and do sport, and will not have any effect on our other lessons. The important thing is not to do best what the teacher teaches; the important thing is to participate in the lesson and to strive for performing the skill. I drew a race field in my drawing (Figure 1). Both the last one and the first one gets 100 points. It is because they participated and made an effort to achieve. I am disturbed by the compulsory attendance for this lesson (Female, P11, 10th class)."

As seen in Table 7, the thoughts of the students with low attitudes about the learning outcomes of physical education lesson are given. The students stated that the physical education lesson should be non-normative and have the content to entertain.
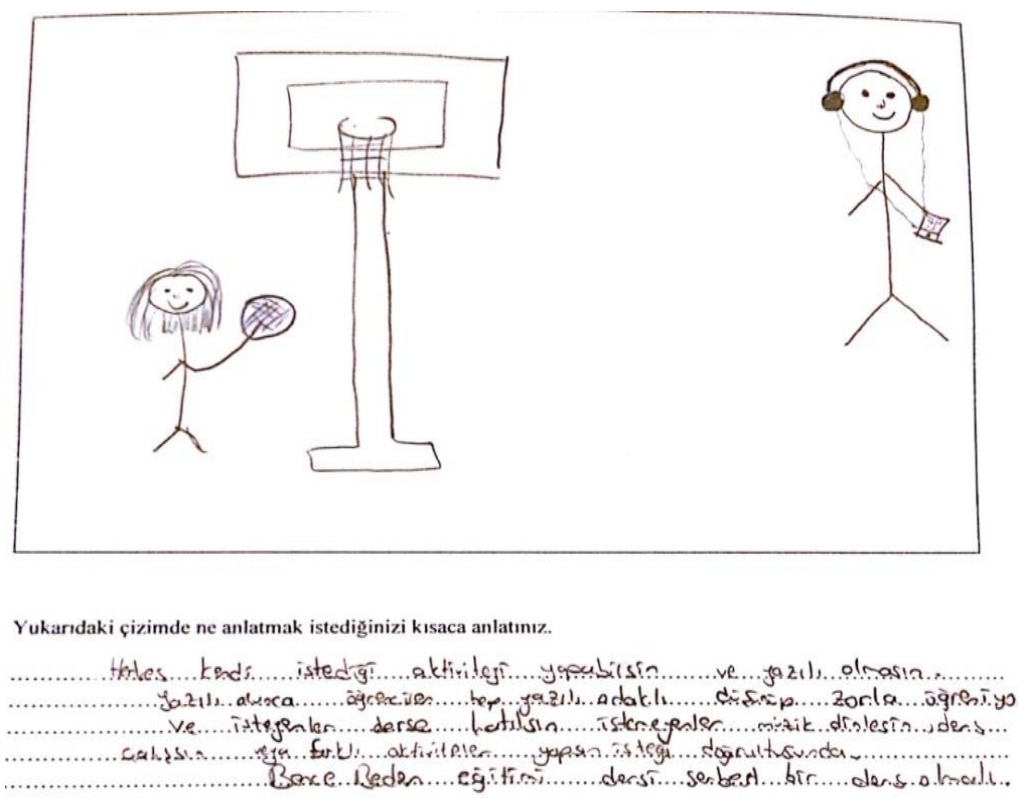

Figure 5. P12 (Sub group, Female, $10^{\text {th }}$ class)

In the drawings, it has been determined that there are gains among the learning outcomes of the physical education course, having a good time, socializing and providing physical development. The students' opinions about the learning outcomes of the lesson are given below.

"The physical education lesson should be for fun. We don't want to get points in the physical education lesson, as well. This creates stress. The lesson should aim to enable us to have fun and have a good time (Female, P3, 10th class)".

"The lesson should contain some activities where we can have a good time and social interaction with our friends. A lesson with strict rules stresses us like other lessons (Male, P6, 10th class)".

The students stated that physical education lesson contributed to affective, physical and social development. They emphasize the necessity of taking into consideration their own expectations in this lesson. In the drawings and interviews, it was seen that students stated that the physical education lesson is a skill-required lesson and that the effort to achieve the skill are enough up to a certain extent, and therefore emphasizing the necessity of taking into account the participation and the endeavor rather than performing the skill perfectly.

The opinions of the science high school students with high attitudes towards physical education lesson are examined under three categories. Their opinions were grouped under three categories: the way of teaching the physical education lesson, the assessment and evaluation of the lesson and the learning outcomes of the lesson (Table 8). 
Table 8. Opinions of students with high attitudes, which were included in their drawings, on physical education lesson

\begin{tabular}{llr}
\hline Categories & Statements & Frequency \\
\hline & $\begin{array}{l}\text { Introduction and implementation of different sportive activities should be } \\
\text { included }\end{array}$ & 3 \\
Expectations for the & Applications to reveal the individual's abilities should be included & 2 \\
Application of the & Increasing the lesson time for learning skills & 2 \\
Lesson & Games should be used when teaching skills & 2 \\
& Opportunity to perform adequate practice for skill acquisition should be & 1 \\
& given & $\mathbf{1 0}$ \\
Assessment and & Total & 2 \\
Evaluation in Physical & Physical education lesson should not affect academic grade point average & 2 \\
Education Lesson & Total & $\mathbf{4}$ \\
& Sportive activities enable learning of different sports branches & 3 \\
Learning outcomes of & It affects personality development positively (self-confidence, sharing, & 2 \\
the Physical & cooperation, etc.) & 2 \\
Education Lesson & It contributes to different areas of development (cognitive, social, physical) & 2 \\
& It provides psychological comfort & $\mathbf{9}$ \\
\hline
\end{tabular}

In Table 8, it is determined that students with a high mean score from physical education lesson attitude scale have different opinions on the way of teaching physical education lesson. The students stated that there should be different sports activities in the lessons and activities should be conducted that can improve students' different skills. It was stated that when teaching skills, different teaching methods (e.g., teaching with game) should be used. In addition, the duration of the lesson is insufficient. The opinions of students about physical education lesson are given below.

"Physical education lesson is a source of motivation for me. We have such heavy lessons that the physical education lesson helps me relax. I feel very fit. I'm learning a lot about the sports. That makes me happy. Other teachers also need to know the contribution of this lesson. Sometimes when other lessons' subjects are not finished, they use this lesson's period to finish them (Male, P17, 9th class)."

"I love this lesson; we can't spend much time with our friends. This lesson improves our communication. We have lots of lessons. And the fact that the teachers and the family see us as a robot that needs to work all the time stresses us. Thanks to this lesson, I can feel relaxed (Male, P23, 9th class)."

"I am satisfied with this lesson. I can only say the volleyball can be included more in the lesson content. I love volleyball. So I want to participate in this event. Lesson content should be shaped according to students' interests and needs (Male, P15, $10^{\text {th }}$ class)."

It was determined that the opinions of the students who have high attitudes change in terms of the assessment and evaluation of the lesson. It was stated that when making an evaluation in the lessons, the process should be taken into consideration and effort should be given importance. As the students who have low scores stated, the physical education lesson should not affect the academic grade point average.

"In the lesson, I want to play only volleyball. But this doesn't involve too many rules. For example, basketball should only be performed as a game rather than an exam. Do not take the points off because of the unimportant things in the exam. This affects our future (Male, P18, 11th class)."

"Physical education lesson should be carried out as a free activity, for fun and pleasant time. In this lesson, we should not experience exam anxiety. This lesson should not contain an exam and content of it should allow us to move, we should recognize the different sports and develop according to our abilities (Male, P15, 10th class)."

Table 9 presents the findings obtained as a result of the interview analyses conducted in order to determine the reasons of the attitudes of the students who make negative statements about the physical education lesson in their drawings. 
Table 9. Reasons for participants' low attitude

\begin{tabular}{lr}
\hline Statements & Frequency \\
\hline Not teaching different sports branches (uniform applications) & 6 \\
Belief that physical education lesson adversely affects academic achievement & 7 \\
Not encouraging talented students to sport & 4 \\
Negative effect of the absence of sports hall on the practices & 8 \\
The dressing room is not clean and hygienic enough & 4 \\
Physical education lesson periods to be taken by other teachers & 3 \\
No applications to uncover the skills of the students & 3 \\
Failure to follow the purpose of the lesson to cause perception of idle lesson & 3 \\
Lack of safe space for sports & 3 \\
Inadequacy of the lesson hours for practices (Inability to reinforce the skill) & 3 \\
Total & $\mathbf{4 4}$
\end{tabular}

It was determined that the implementation of the physical education lesson did not meet the expectations of the students, that students wanted to learn knowledge and skills specific to different sports branches and the lesson time and the style of lesson application did not meet these expectations. Some of the students suggested that physical education teachers should have reveal their skills specific to any branch of sports. Some of the students' opinions on this are given below.

"I love sports since primary school. The physical education lesson is not considered valuable in schools. We would look directly at the teachers' eyes so they could see the talent we had, so that we can get in the school sports team, that they can discover us. Teachers should realize this instead of us. Instead of being given time by giving a ball to us, they should follow us and discover our skills. Most of my friends call it idle lesson and rejoice because physical education lesson is not done properly. Being an idle lesson is not something to love (Female, P1, 11th class, sub group)."

"The way of lesson application is not a problem; we are given information about sports branches. But then we're free again. The lesson is very inefficient. What I want is not to take the ball in my hand and do activities with my friends, but I would like to improve myself in a more academic way. It is because the skills become clear when you are a child. Unfortunately, there was no orientation for this (Female, P2, 9th class, sub group).”

"Physical education lesson should be adapted first by physical education teacher. This can be done by preparing the content of the lesson efficiently, actively participating in the lesson, following the development of the student, giving the student positive or negative feedback when teaching the skill. As a student, we and our family will then understand that this lesson has been handled properly and contributed to us. My family doesn't react as in a math class when it is about the physical education lesson. They say it is just a physical education lesson, you don't have to worry about it that much..." (Female, P3, 10th class) (Reflection of negative perception of society).

\section{Discussion}

It was found out that the attitude mean score of the science high school students was $3.21 \pm 0.98$ in this study examining their opinions on the physical education lesson. Considering the mean score that can be taken from the scale, it can be said that the students have a moderate attitude. The findings of the study in the literature on the subject are similar. Jurisin, Malcic \& Kostovic, (2017) found in their study that students' attitude towards physical education lessons were moderate. Other studies examining the attitudes of adolescents towards physical education lesson (Brayan \& Solmon, 2012; Chatterjee, 2013) support the current finding. In the literature, there are also studies in which students have high attitudes towards physical education lesson (Aybek, Taşmektepligil \& İmamoğlu, 2017; Howard, Zeng \& Raymond, 2011). PE has the potential to provide students with positive sport experiences by bringing students together in a shared interest, providing a sense of belonging to a team, offering opportunities for developing valued competencies and capabilities, and developing social networks and community cohesion (Bailey, 2005).

The attitudes of the students towards physical education lesson vary according to the gender variable. This difference is in favor of male students $(3.35 \pm 0.76)$. There are studies supporting the current findings in the literature (Arabac1, 2009; Ekici, Bayrakdar \& Hacıcaferoğlu, 2011; Hünük \& Demirhan, 2003; Flores, Salguero \& Marquez, 2008; Özkara \& Kalkavan, 2018; Subramaniam \& Silverman, 2007; Zeng, Hipscher \& Leung, 2011). Studies showing that there is no significant difference towards physical education lesson according to gender are also present in the literature (Gürbüz \& 
Özkan, 2012). It was determined that there are differences in the study findings which measure the attitudes of students towards physical education lesson. It can be said that this can be due to the characteristics of the sample group examined. In the present study, it was determined that the attitudes of male students towards the lesson were higher than the female students. The qualitative findings of the study support this result. In the drawings and interviews, it was determined that the female students had negative opinions about physical education lesson. Among the reasons of these negativities, it was stated by the students that there are deficiencies related to the way of teaching the physical education lesson and that it adversely affects academic achievement. The students stated that physical education teachers did not include different sports branches in the lesson application and did not have any activities that might reveal their skills. A similar finding was also reported in the study by Sunay \& Sunay (1996) examining the expectations of high school students for physical education. In the study, it was stated that the students wanted teachers to reveal their special skills in a sports branch through the lesson. However, half of the students stated that these expectations were not met. In our current study, students of science high schools emphasized that the lesson should be carried out in accordance with its objectives. Otherwise, it was said by students that parents and teachers considered the lesson as an idle lesson. The female student, who has a negative attitude despite her love to the lesson since the lesson is not carried out in accordance with its objectives, explained the reason for her negative attitude towards the lesson as follows: "The physical education lesson is not considered valuable in schools. We would look directly at the teachers' eyes so they could see the talent we had, so that we can get in the school sports team, that they can discover us. Teachers should realize this instead of us. Instead of being given time by giving a ball to us, they should follow us and discover our skills. Most of my friends call it idle lesson and rejoice because physical education lesson is not done properly". In the study of Sunay \& Sunay (1996), it was stated that students expect to be directed to a sports branch and to be selected for the school sports teams. However, in practice, it was found that these expectations did not provide sufficient response.

No difference was found in student attitudes according to class level. This is similar in the qualitative part of the research. As academic achievement is important for students of Science High School, both 9th and 11th class students stated that physical education lesson should be done in accordance with its objectives, otherwise it can be perceived as a wasted time. They also stated that this lesson mentally relaxes them and keeps them fit. The students stated that other lessons caused cognitive fatigue, and they made great efforts to pass the lessons successfully. The physical education lesson reduces the cognitive fatigue caused by other lessons and increases the psychological resistance (Sunay \& Sunay, 1996). In our study, the male student expressed the psychological comfort provided by the physical education lesson with the following words: "Physical education is a source of motivation for me. We have so many difficult lessons; physical education helps me relax. I feel very fit. I'm learning a lot about the sports. That makes me happy". They stated that they see physical education lesson as an opportunity for more fun and cognitive relaxation. For this reason, the students stated that the exams of physical education lesson should not be in a way that will force the students of science high schools. It was stated by the 9th class female student that there should not be an exam for physical education lesson. The student expresses this opinion in these words: "I think that this lesson is an escape and relaxation tool for resting our head and decreasing the stress of examination. I'm already stressed out. I also don't want to stress over the exam of the physical education lesson."

In the study, no significant relationship was found between academic achievement and attitudes of students towards physical education lesson. In particular, students stated that physical education lesson negatively affected academic achievement. Koç \& Tamer (2016) argued that academic failure is a great source of motivation for sportive success, and that those with low academic achievement can show a better sportive performance. Yilmaz (2018) in a study conducted on the parents stated that parents do not want to direct their children to sportive activities due to the concern that children's academic achievement will decrease. Similar findings are present in the study of Y1lmaz \& Cihan (2018). In the study, the students stated that their parents want them to spend time to the lessons they can improve themselves academically rather than the sportive activities. In our current study, the students stated that their parents support the participation in physical education lesson but they don't give as much important as the other lessons. They explained the reason for this situation as not being responsible for this lesson for the university exam that will shape their future (Yilmaz, 2016). However, as Bailey (2005) stated, this lesson contributes to many areas of development of children. Physical education lessons provide the students with the opportunity to act for a common purpose, have the feeling of belonging to a group/team, realize and develop their ability. According to Ding \& Sugiyama (2017), physical education lesson offers offer the learning outcomes such as positive sports experience, body language and communication. In addition, physical education lesson provides students with the opportunity to see their strengths and weaknesses (Sunay \& Sunay, 1996). In our current study, in the opinions of the students, it was emphasized that they are aware of the effects of physical education lesson on different development areas and the lesson content should be designed in such a way that will contribute to the development areas. Carpenter (2010) stated that physical education teachers need to present the lesson content in such a way that students can gain positive experiences. 
The students of Science High School stated that they had some negative experiences about the learning outcomes of the physical education lesson, the way of teaching the lesson and the assessment and evaluation of the lesson. Particular emphasis is placed on the necessity for this group, for whom academic achievement is of utmost importance, that evaluation of the physical education lesson should be based on the efforts to perform the skills. It is stated that the physical education lesson is a subject that requires talent and that everyone cannot be talented and that in this case, it is necessary to take the participation in the lesson and efforts to perform the skills as a criterion in the assessment and evaluation. Otherwise, they stated that physical education lesson became a punishment rather than a reward. It shows that students have great anxiety about assessment and evaluation in physical education lesson.

\section{Suggestions}

1. Physical education lesson content should be in accordance with the interests, needs and expectations of the students.

2. The lesson content should contribute to the permanence of learning by using different teaching methods and techniques.

3. The knowledge and skills regarding the different sports branches should be presented to the students in the content of physical education lesson.

4. In the physical education lesson, student participation and efforts should be taken into consideration in assessment and evaluation.

5. Participation of teacher with the students in the activities may contribute to the positive attitude of the student to the lesson.

6. Lesson content should be provided to enable students to explore and recognize their talents.

\section{Acknowledgements}

Collate acknowledgements in a separate section at the end of the article before the references. List here those individuals who provided help during the research (e.g., providing language help, writing assistance or proof reading the article, etc.); Identify grants or other financial support (and the source, if appropriate) for your study.

\section{References}

Arabac1, R. (2009). Attitudes toward physical education and class preferences of Turkish secondary and school students. Elementary Education Online, 8(1), 2-8.

Ayas, A. (2006). Kavram öğrenme [Concept learning]. S. Çepni (Ed.). Fen ve teknoloj öğretiminde teoriden uygulamaya [From theory to practice in science and technology teaching] (p.192-221). Ankara: Pegem Publication.

Aybek, A., İmamoğlu, O., \& Taşmektepligil, M. Y. (2012). Evaluating the students' attitudes toward physical education class and extracurricular activities. Ondokuz Mayls University Journal of Sports and Performance Research, 2(2), 51-59.

Backett-Milburn, K., \& McKie, L. (1999). A critical appraisal of the draw and write technique. Health Education Research, 14(3), 387-398. https://doi.org/10.1093/her/14.3.387

Bailey, R. (2005). Evaluating the Relationship between Physical Education, Sport and Social Inclusion. Educational Review, 57, 71-90. https://doi.org/10.1080/0013191042000274196

Boreham, C., \& Riddoch, C. (2001). The physical activity, fitness and health of children. Journal of Sports Sciences, 19, 915-929. https://doi.org/10.1080/026404101317108426

Bradding, A., \& Horstman, M. (1999). Using the write and draw technique with children. European Journal of Oncology Nursing, 3(3), 170-175. https://doi.org/10.1016/S1462-3889(99)80801-1

Bryan, C. L., \& Solmon, M. A. (2012). Student motivation in physical education and engagement in physical activity. Journal of Sport Behavior, 35(3), 267-285.

Büyüköztürk, Ş. (2008). Sosyal bilimlerde very analizi el kitabı [Data analysis guidebook for social sciences] (9. Edition). Ankara: Pegem Akademi Pub.

Carpenter, E. J. (2010). The tactical games model sport experience an examination of student motivation and game performance during an ultimate frisbee unit. Doctor Dissertation, University of Massachusetts.

Chatterjee, S. (2013). Attitudes toward physical education of school going adolescent in West Bengal. International Journal of Innovative research in Science, Engineering and Technology, 2, 6068-6073.

Creswell, J. W. (2014). Research design: Quantitative, qualitative and mixed method approaches (Fourth Edition). 
London: Sage Pub.

Creswell, J. W., \& Clark, V. L. P. (2007). Designing conducting mixed methods research. Thousand Oaks, CA: Sage.

Ding, J., \& Sugiyama, Y. (2017). Exploring influences of sport experiences on social skills in physical education classes in college students. Advances in Physical Education, 7, 248-259. https://doi.org/10.4236/ape.2017.73020

Ekici, S., Bayrakdar, A., \& Hacicaferoğlu, B. (2011). Assessing the attitudes of the high school students toward physical education class. International Journal of Human Sciences, 8(1), 829-839.

Ersoy, A., \& Türkkan, B. (2009). Perceptions about Internet in elementary school children's drawings. Elementary Education Online, 8(1), 57-73.

Flores, J., Salguero, A., \& Marquez, S. (2008). Goal orientations and perceptions of the motivational climate in physical education classes among colombian students. Teaching and Teacher Education, 24(6), 1441-1449. https://doi.org/10.1016/j.tate.2007.11.006

Freedman, M. (1993) The kindness of strangers: Adult mentors, urban youth, and the new volunteerism. San Francisco: Jossey-Bass.

Güllü, M., \& Güçlü, M. (2009). Devoloping of attitude scale of physical education lesson for secondary education students. Niğde Üniversity Physical Education and Sport Science, 3(2), 138-151.

Gürbüz, A., \& Özkan, H. (2012). Determining the attudie of secondary school students toward physcal education of sport lesson (Muğla sample). Pamukkale Journal of Sport Science, 3(2), 78-89.

Howard, Z., Zeng, M. H., \& Raymond W. L. (2011). Attitudes of high school students toward physical education and their sport activity preferences. Journal of Social Sciences, 7(4), 529-537. https://doi.org/10.3844/jssp.2011.529.537

Howie, E. K., \& Pate, R. R. (2012). Physical activity and academic achievement in children: A historical perspective. Journal of sport and health science, 1(3), 160-169. https://doi.org/10.1016/j.jshs.2012.09.003

Hünük, D., \& Demirhan G. (2003). Comparison of primary school, secondary school and university students' attrrude toward physical education and sports. Hacettepe Journal of Sport Science, 14 (4), 175-184.

Jurišin, S. M., Malčić, B., \& Kostović, S. (2017). Attitudes of junior adolescents toward physical education through the prism of contextual factors and traits of a child. Journal of Physical Education and Sport, 17, 2207-2213.

Kirkendall, D. R. (1986). Effect of physical activity on intellectual development and academic performance. In Academy Papers Edited by: Stull GA. Champaign, IL: Human Kinetics.

Kjønniksen, L., Fjørtoft, I., \& Wold, B. (2009). Attitude to physical education and participation in organized youth sports during adolescence related to physical activity in young adulthood: A 10-year longitudinal study. European Physical Education Review, 15(2),139-154. https://doi.org/10.1177/1356336X09345231

Knighting, K., Rowa Dewar, N., Malcolm, C., Kearney, N., \& Gibson, F. (2011). Children's understanding of cancer and views on health related behaviour: A 'draw and write'study. Child: Care, Health and Development, 37(2), 289-299. https://doi.org/10.1111/j.1365-2214.2010.01138.x

Koç, Y., \& Tamer, K. (2016). A study on the sportsmanship behaviors of female students in physical education course according to different variables. Nigde University Journal of Physical Education and Sport Sciences, 7(1), 16-27.

Miles, M. B., \& Huberman, A. M. (1994). Qualitative data analysis: An expanded sourcebook. Sage.

Morgan, P. J., Saunders, K. L., \& Lubans, D. R. (2012). Improving physical self-perception in adolescent boys from disadvantaged schools: Psychological outcomes from the physical activity leaders randomized controlled trial. Pediatric Obesity, 7(3), 27-32. https://doi.org/10.1111/j.2047-6310.2012.00050.x

Özkara, A. B. (2018) Physical education in Eu Schools and Turkey: A comparative study, Comparative Professional Pedagogy, 8(2), 101-106. https://doi.org/10.2478/rpp-2018-0026

Özkara, A. B., \& Kalkavan, A. (2018). A validity and reliability study of the body coordination test for children in a group of Turkish middle schoolers. SPORMETRE Journal of Physical Education and Sport Science, 16(4), 1-11.

Punch, K. F. (2005). Introduction to social research: Quantitative and qualitative approaches. (Second Edition) London: Sage Pub.

Sollerhed, A. C., Ejlertsson, G., \& Apitzsch, E. (2005). Predictors of strong sense of coherence and positive attitudes to physical education in adolescents. Scandinavian Journal of Public Health, 33(5), 334-342. https://doi.org/10.1080/14034940510005833 
Strong, W. B., Malina, R. M., Blimkie, C. J. R., Daniels, S. R., Dishman, R. K., Gutin, B., .. Trudeau, F. (2005): Evidence based physical activity for school-age youth. Journal of Pediatrics, 146(6), 732-737 https://doi.org/10.1016/j.jpeds.2005.01.055

Subramaniam, P. R., \& Silverman, S. (2007). Middle school students' attitudes toward physical education. Teaching and Teacher Education, 23(5), 602-611. https://doi.org/10.1016/j.tate.2007.02.003

Sunay, Y., \& Sunay, H. (1996). The expectation of high school students from physcial education lessons and the level of realization of the expectations. Gazi University Journal of Physical Education and Sport Science, 1(4), 35-53.

Tamer, K., \& Pulur, A. (2001). Beden eğitimi ve sporda öğretme yöntemleri [Teaching methods in physical education and sport]. Ankara: Ada Pub.

Taneri, P. O., \& Demir, C. E. (2013). Implementation of life sciences from the perspectives of students: Creative drama as a qualitative data collection method. Elementary Education Online, 12(1), 267-282.

Taras, H. (2005). Physical activity and student performance at school. J Sch Health, 75, 214-218. https://doi.org/10.1111/j.1746-1561.2005.00026.x

Taşmektepligil, Y., Yılmaz, Ç., İmamoğlu, O., \& Kılcıgil, E. (2006). Level of actualizing the physical education class goals in elementary schools. SPORMETRE Journal of Physical Education and Sports Sciences, 4(4), 139-147.

Trudeau, F., \& Shephard, R. J. (2008). Physical education, school physical activity, school sports and academic performance. International Journal of Behavioral Nutrition and Physical Activity Review, 5(10), 1-12. https://doi.org/10.1186/1479-5868-5-10

Yalçı, M., \& Erginer, A. (2014). Primary school students's drawings on the perceptions of school principal. Education and Science, 39(171), 270-285.

Yıldırım, A., \& Şimşek, H. (2011). Nitel araştırma yöntemleri [Qualitative research methods]. Ankara: Seçkin Pub.

Y1lmaz (2016). Parents' attitude and opinions towards participation to extracurricular sport activity of high school students. Unpublished doctoral thesis. Ankara, Turkey.

Yilmaz, A. (2018). Attitudes towards physical education course and extracurricular sport activities of parents. Niğde Üniversity Physical Education and Sport Science, 12, 48-64.

Yilmaz, A., \& Cihan, H. (2018). Determination the views of head-teacher, physical education teachers and students towards the physical education in the secondary education schools: Quanlitative research. Gazi University Journal of Physical Educational and Sport Science, 23, 9-24

Yılmaz, A., \& Güven, Ö. (2015). The Investigation of gifted students' perceptions about concepts like "physical education course and physical education teacher" through drawing-writting methodology. Journal of Qualitative Research in Education - JOQRE, 3(3), 55-77. https://doi.org/10.14689/issn.2148-2624.1.3c3s3m

Yılmaz, A., Esentürk, O. K., Pala, Ş., \& İlhan, E. L. (2017). Sports environment perceptions of preschool children. Science, Movement and Health, 17(2), 247-255.

Zeng, H. Z., Hipscher, M., \& Leung, R. W. (2011). Attitudes of high school students toward physical education and their sport activity preferences. Journal of Social Sciences, 7(4), 529-537. https://doi.org/10.3844/jssp.2011.529.537

\section{Copyrights}

Copyright for this article is retained by the author(s), with first publication rights granted to the journal.

This is an open-access article distributed under the terms and conditions of the Creative Commons Attribution license which permits unrestricted use, distribution, and reproduction in any medium, provided the original work is properly cited. 